\title{
IMPLEMENTASI PENDIDIKAN KARAKTER DI SMP NEGERI 2 KLATEN DAN MTS. WAHID HASYIM YOGYAKARTA
}

\author{
Agus Sudarsono, Sudrajat, Satriyo Wibowo \\ Pendidikan IPS, Fakultas Ilmu Sosial, UNY \\ Email: sudrajat@uny.ac.id,Hp: 085743430029
}

\begin{abstract}
Abstrak
Penelitian ini bertujuan untuk mengetahui: 1) persepsi kepala sekolah, ustadz, guru, dan pengasuh tentang pendidikan karakter; 2) implementasi pendidikan karakter di SMP Negeri 2 Klaten dan MTs. Wahid Hasyim; 3) kebijakan sekolah dalam implementasi pendidikan karakter di SMP Negeri 2 Klaten dan MTs. Wahid Hasyim; 4) peran serta warga sekolah dalam implementasi pendidikan karakter di SMP Negeri 2 Klaten dan MTs. Wahid Hasyim. Metode penelitian yang dipergunakan adalah penelitian kualitatif. Teknik pengumpulan data yang dipergunakan yaitu: wawancara, observasi, dan dokumentasi. Teknik analisis data menggunakan teknik analisis intraktif model Miles dan Huberman yang meliputi kegiatan: pengumpulan data, reduksi data, penyajian data, dan penarikan kesimpulan. Hasil penelitian menunjukkan bahwa: 1) kepala sekolah, guru, ustadz mempunyai persepsi yang memadai tentang pendidikan karakter. 2) implementasi pendidikan karakter di MTs. Wahid Hasyim mengacu pada nilai-nilai religious dengan mengintegrasikan inkulkasi nilai dalam seluruh aktivitas santri baik di dalam pembelajaran, ekstra kurikuler, kegiatan belajar, mengaji, makan, istirahat, dan lainlain; 3) program pendidikan karakter telah dirancang oleh wakil kepala bidang kurikulum dan pengajaran, sedangkan di MTs. Wahid Hasyim dirancang oleh kepala madrasah.; 4) peran serta warga sekolah baik guru/ustadz, pembimbing, karyawan, dan masyarakat sekitar mempunyai peran yang signifikan.
\end{abstract}

Kata Kunci: Pendidikan karakter, SMPN 2 Klaten, MTs. Wahid Hasyim 
Agus Sudarsono, Sudrajat, Satriyo Wibowo

\begin{abstract}
This study aims to determine: 1) the perception of principals, teachers, teachers, and caregivers about character education; 2) implementation of character education in SMP Negeri 2 Klaten and MTs. Wahid Hasyim; 3) The school policies in the implementation of character education in SMP Negeri 2 Klaten and MTs. Wahid Hasyim; 4) the role of the school community in the implementation of character education in SMP Negeri 2 Klaten and MTs. Wahid Hasyim. The research method used was qualitative research. Data collection techniques used are: interviews, observation, and documentation. Data were analyzed using analysis techniques intraktif model of Miles and Huberman which includes: data collection, data reduction, data presentation, and conclusion. The results showed that: 1) the principal, teachers, religious teacher has an adequate perception of character education. 2) implementation of character education in MTs. Wahid Hasyim reference to religious values by integrating inkulkasi values in all activities of students both in learning, extra-curricular, learning, lessons, eat, rest, and others; 3) The character education program has been designed by the deputy head of curriculum and instruction, whereas in MTs. Wahid Hasyim designed by headmaster .; 4) the role of the citizens of both school teachers / teachers, counselors, employees and the surrounding communities have a significant role.
\end{abstract}

Keywords: character education, SMPN 2 Klaten, MTs. Wahid Hasyim

\title{
Pendahuluan
}

Pendidikan merupakan pilar tegaknya suatu bangsa, melalui pendidikan suatu bangsa akan tegak mampu menjaga martabatnya. Pada dasarnya pendidikan diselenggarakan dalam rangka membebaskan manusia dari berbagai persoalan hidup yang melingkupinya. Bagi Paulo Freire (Firdaus M Yunus, 2007: 1) pendidikan merupakan salah satu upaya untuk mengembalikan fungsi manusia menjadi manusia agar terhindar dari berbagai bentuk penindasan, kebodohan sampai kepada ketertinggalan. Oleh karenanya manusia sebagai pusat pendidikan harus menjadikan pendidikan sebagai alat pembebasan untuk mengantarkan manusia menjadi makhluk yang bermartabat. 
Dalam proses ini pendidikan dimaknai sebagai proses pembentukan kepribadian dan pengembangan seseorang sebagai makhluk individu, sosial, susila, dan makhluk yang beragama. Kesemuanya menghendaki manusia menjadi makhluk yang seimbang sehingga diharapkan pendidikan dapat menyediakan proses untuk mencapai tujuan tersebut.

John Dewey (Ornstein \& Levis, 1989: 139) mengemukakan bahwa education is that reconstruction or reorganization of experience and which increases ability to direct the course of subsequent experience. Dalam kalimat tersebut terkandung pengertian bahwa pendidikan merupakan rekonstruksi dari pengalaman-pengalaman yang secara langsung meningkatkan kemampu-an seseorang dalam menghadapi pengalaman berikutnya. Dengan demikian pendidikan harus diarahkan pada upaya untuk membangun kemampuan kognitif serta kematangan emosional peserta didik sehingga ia dapat memecahkan permasalahan yang semakin kompleks.

Pendidikan karakter merupakan suatu penanaman nilainilai karakter kepada warga sekolah yang meliputi komponen pengetahuan, kesadaran atau kemauan dan tindakan untuk melaksanakan nilai-nilai tersebut. Dalam pendidikan karakter di sekolah, semua komponen (pemangku pendidikan) harus dilibatkan, temasuk komponen-komponen pendidikan itu sendiri yaitu isi kurikulum, proses pembelajaran dan penilaian, penanganan atau pengelolaan mata pelajaran, pengelolaan sekolah, pelaksanaan aktivitas atau kegiatan kurikuler, pemberdayaan sarana prasarana, pembiayaan dan etos kerja seluruh warga sekolah/lingkungan.

Pendidikan karakter merupakan upaya-upaya yang dirancang dan dilaksanakan secara sistematis untuk membantu 
Agus Sudarsono, Sudrajat, Satriyo Wibowo

peserta didik memahami nilai-nilai perilaku manusia yang berhubungan dengan Tuhan, diri sendiri, sesama manusia, lingkungan dan kebangsaan yang terwujud dalam pikiran, sikap, perasaan, perkataan dan perbuatan berdasarkan norma-norma agama, hukum, tata krama, budaya dan adat istiadat. Pendidikan karakter harus berkelanjutan dan tidak pernah berakhir (never ending process), sebagai bagian terpadu untuk menyiapkan generasi bangsa, yang sesuai dengan sosok manusia masa depan, berakar pada filosofi dan nilai kultur religius bangsa Indonesia. Pendidikan karakter harus menumbuhkembangkan filosofi dan pengalaman atas keseluruhan karakter bangsa ini secara utuh, dan menyeluruh. Oleh karena itu, merupakan langkah yang positif ketika pemerintah (Mendiknas) merevitalisasi pendidikan karakter dalam seluruh jenis dan jenjang pendidikan.

Melalui revitalisasi dan penekanan karakter di berbagai lembaga pendidikan, baik informal, formal, maupun nonformal; diharapkan bangsa Indonesia mampu menjawab berbagai tantangan dan permasalahan yang semakin rumit dan kompleks. Hal ini penting, karena dalam era globalisasi, perkembangan ilmu pengetahuan, teknologi dan seni berlangsung begitu pesat, dan tingginya mobilitas manusia karena jarak ruang dan waktu menjadi sangat relatif. Dalam pendidikan karakter di sekolah, semua komponen (stakeholders) harus dilibatkan, termasuk komponen-komponen yang ada dalam sistem pendidikan itu sendiri, yaitu isi kurikulum, rencana,pembelajaran, proses pembelajaran, mekanisme penilaian, kualitas hubungan, pengelolaan pembelajaran, pengelolaan sekolah, pelaksanaan pengembangan diri peserta didik, pemberdayaan sarana prasarana, pembiayaan, serta etos kerja seluruh warga dan lingkungan sekolah. 
Sekolah sebagai institusi pendidikan memberikan fondasi terpenting dalam kehidupan anak-anak di kemudian hari. Lingkungan pendidikan yang aman, asri, nyaman, dan kondusif akan mampu memberikan lingkungan sosial dan budaya yang konstruktif bagi perkembangan karakter siswa. Pendidikan model asrama (boarding school) yang akhir-akhir ini popular di kalangan masyarakat merupakan model persekolahan yang patut mendapatkan perhatian karena keberhasilannya dalam proses pembentukan karakter dan watak anak-anak menjadi pribadi yang lebih baik. Namun pendidikan model konvensional seperti SMP Negeri 2 Klaten juga patut mendapatkan perhatian karena sekolah tersebut mencoba menerapkan pendidikan karakter dalam berbagai aspek kegiatan pendidikan. Dalam penelitian ini akan dibandingkan model implementasi pendidikan karakter di sekolah model konvensional dan sekolah model berasrama dengan rumusan masalah sebagai berikut: 1) bagaimanakah persepsi kepala sekolah, guru, dan karyawan tenaga pendidikan terhadap pendidikan karakter; 2) bagaimanakah implementasi pendidikan karakter di SMP N2 Klaten dan Mts. Wahid Hasyim, 3) bagaimanakah hambatannya di kedua lembaga pendidikan tersebut.

\section{Hakikat Pendidikan Karakter}

Karakter dimaknai sebagai cara berpikir dan berperilaku yang khas setiap individu untuk hidup dan bekerjasama, baik dalam lingkup keluarga, masyarakat dan negara. Karakter yang kuat mampu memberikan kemampuan kepada manusia untuk hidup bersama dalam kedamaian serta membentuk dunia yang dipenuhi dengan kebaikan dan kebijakan, yang bebas dari kekerasan dan tindakan-tindakan tidak bermoral. Pendidikan 
Agus Sudarsono, Sudrajat, Satriyo Wibowo

karakter adalah hal positif apa saja yang dilakukan guru dan berpengaruh kepada karakter siswa yang diajarnya. Pendidikan karakter adalah upaya sadar dan sungguh-sungguh dari seorang guru untuk mengajarkan nilai-nilai kepada para siswanya (Winton, 2010).

Jadi, pendidikan karakter adalah proses pemberian tuntunan kepada peserta didik untuk menjadi manusia seutuhnya yang berkarakter dalam dimensi hati, pikir, raga, serta rasa dan karsa. Pendidikan dapat dimaknai sebagai pendidikan nilai, pendidikan budi pekerti, pendidikan moral, pendidikan watak, yang bertujuan mengembangkan kemampuan peserta didik untuk memberikan keputusan baik-buruk, memelihara apa yang baik, dan mewujudkan kebaikan itu dalam kehidupan sehari-hari dengan sepenuh hati. Hal ini sesuai dengan UU. No. 20 Tahun 2003 tentang Sistem Pendidikan Nasional dimana Pasal 3 menyebutkan:

Pendidikan nasional berfungsi mengembangkan kemampuan dan membentuk karakter serta peradaban bangsa yang bermartabat dalam rangka mencerdaskan kehidupan bangsa. Pendidikan nasional bertujuan memperkembangkan potensi peserta didik agar menjadi manusia beriman dan bertakwa kepada Tuhan Yang Maha Esa, berakhlak mulia, sehat, berilmu, cakap, kreatif, mandiri dan menjadi warga negara yang demokratis serta bertanggung jawab.

Berdasarkan fungsi dan tujuan pendidikan nasional, jelas bahwa pendidikan di setiap jenjang harus diselenggarakan secara sistematis guna mencapai tujuan tersebut. Pendidikan karakter memiliki makna lebih tinggi dari pendidikan moral, karena pendidikan karakter tidak hanya berkaitan dengan masalah benar-salah, tetapi bagaimana menanamkan kebiasaan tentang hal-hal yang baik dalam kehidupan, sehingga peserta didik memiliki kesadaran, dan pemahaman yang tinggi, serta kepedulian 
dan komitmen untuk menerapkan kebijakan dalam kehidupan sehari-hari.

Mulyasa (2011:1) mendefinisikan pendidikan karakter sebagai upaya membantu perkembangan jiwa anak-anak baik lahir maupun batin, dari sifat kodratinya menuju kearah peradaban manusiawi dan lebih baik. Pendidikan karakter sebagai upaya untuk mempromosikan dan menginternalisasikan nilai-nilai utama, atau nilai-nilai positif kepada warga masyarakat agar menjadi warga bangsa yang percaya diri, tahan uji dan bermoral tinggi, demokratis dan bertanggung jawab serta survive dalam kehidupan bermasyarakat (Kusnaedi, 2013: 19).

\section{Tujuan Pendidikan Karakter}

Menurut Kemendiknas (2010) Pendidikan Karakter bertujuan mengembangkan nilai-nilai yang membentuk karakter bangsa yaitu Pancasila, meliputi: (1) mengembangkan potensi peserta didik agar menjadi manusia berhati baik, berpikiran baik dan berperilaku baik; (2) membangun bangsa yang berkarakter Pancasila; (3) mengembangkan potensi warganegara agar memiliki sikap percaya diri, bangga pada bangsa dan negaranya serta mencintai umat manusia.

Thomas Lickona (2000) menyatakan beberapa nilai kebaikan yang perlu dihayati dan dibiasakan dalam kehidupan peserta didik agar tercipta kehidupan yang harmonis di lingkungan sekolah, dalam keluarga dan masyarakat. Beberapa nilai itu antara lain: kejujuran, kasih sayang, pengendalian diri, saling menghargai/menghormati, kerjasama, tanggung jawab, dan tekun. Selanjutnya Anne Lockwood (2008: 3) merinci ada tiga proporsi sentral dalam pendidikan karakter. Pertama, bahwa tujuan pendidikan moral dapat dikejar/dicapai, tidak semata-mata membiarkannya sekedar sebagai kurikulum tersembunyi yang 
Agus Sudarsono, Sudrajat, Satriyo Wibowo

tidak terkontrol, dan bahwa tujuan pendidikan karakter telah memiliki dukungan yang nyata dari masyarakat dan telah menjadi konsensus bersama. Kedua bahwa tujuan-tujuan behavioral tersebut adalah bagian dari pendidikan karakter, dan ketiga, perilaku antisosial sebagai bagian kehhidupan anak-anak adalah sebagai hasil dari ketidakhadiran nilai-nilai dalam pendidikan.

\section{Strategi Pendidikan Karakter}

Pendidikan karakter di sekolah dapat dilakukan secara efektif dan efisien apabila didukung oleh sumber daya manusia yang profesional untuk mengoperasikannya, dana sekolah yang cukup untuk menggaji staf sesuai fungsinya, sarana prasarana yang memadai untuk mendukung proses pembelajaran, serta dukungan yang tinggi dari masyarakat (orang tua). Tata tertib sekolah berperan penting dalam upaya pembiasaan, internalisasi, dan pengendalian karakter siswa melalui strategi sebagai berikut:

a) Sekolah membuat tata tertib untuk siswa, guru dan karyawan yang mengandung unsur pengembangan karakter

b) Peraturan sekolah dipahami oleh siswa, guru dan karyawan

c) Peraturan sekolah disosialisasikan kepada orang tua

d) Peraturan sekolah telah membudaya di sekolah

e) Penegakan peraturan sekolah dilaksanakan dengan menerapkan sanksi dan reward yang jelas dan adil untuk menimbulkan kesadaran dan motivasi dalam pembentukan karakter siswa.

f) Staf kesiswaan melakukan kajian rutin tentang pelanggaran tata tertib sekolah

g) Staf kesiswaan melakukan pembinaan dan bimbingan kepada siswa yang melanggar aturan

h) Staf kesiswaan memantau keterlaksanaan tata tertib sekolah 
i) Staf kesiswaan mendokumentasikan jenis dan jumlah pelanggaran serta pembinaan yang telah dilakukan

j) Guru dan karyawan dapat memberikan teladan dalam penerapan tata tertib sekolah di sekolah

\section{Indikator Keberhasilan Pendidikan Karakter}

Keberhasilan program pendidikan karakter dapat diketahui melalui pencapaian pencapaian indikator oleh peserta didik sebagaimana tercantum dalam Standar Kompetensi Kelulusan setiap sekolah yang meliputi:

\begin{tabular}{|c|c|}
\hline No. & \\
\hline 1 & $\begin{array}{l}\text { engamalkan ajaran agama yang dianut sesuai de } \\
\text { hap perkembangan remaja; }\end{array}$ \\
\hline 2 & i kekurangan dan kelebihan diri sendiri; \\
\hline 3 & kan sikap perca \\
\hline 4 & $\begin{array}{l}\text { ematuhi aturan-aturan sosial yang berlaku dalam } \\
\text { ngkungan yang lebih luas; }\end{array}$ \\
\hline 5 & $\begin{array}{l}\text { ai keberagaman agama, budaya, su } \\
\text { sosial ekonomi dalam lingkungan yar }\end{array}$ \\
\hline 6 & $\begin{array}{l}\text { formasi dari lingk } \\
\text { cara logis, kritis da }\end{array}$ \\
\hline 7 & kan kemampuan berpikir logis, kritis, kreatif dan \\
\hline 8 & $\begin{array}{l}\text { kkan kemampuan belajar secara mandiri sesuai } \\
\text { otensi yang dimilikinya; }\end{array}$ \\
\hline 9 & $\begin{array}{l}\text { menganalisis dan } \\
\text { ehari-hari; }\end{array}$ \\
\hline 10 & dan sosial; \\
\hline 11 & secara bertangg \\
\hline 12 & $\begin{array}{l}\text { Menerapkan nilai-nilai kebersamaan dalam kehidupan } \\
\text { bermasyarakat, berbangsa, dan bernegara demi } \\
\text { terwujudnya persatuan dalam negara kesatuan Republik } \\
\text { Indonesia; }\end{array}$ \\
\hline 13 & budaya nasional; \\
\hline 14 & $\begin{array}{l}\text { rgai tugas pekerjaan dan memiliki kema } \\
\text { erkarya; }\end{array}$ \\
\hline 15 & $\begin{array}{l}\text { pkan hidup bersih, sehat, bugar, } \\
\text { faatkan waktu luang dengan baik; }\end{array}$ \\
\hline 16 & nikasi dan berin \\
\hline 17 & $1 y^{d a}$ \\
\hline
\end{tabular}


Agus Sudarsono, Sudrajat, Satriyo Wibowo

\begin{tabular}{|c|l|}
\hline 18 & pendapat; \\
\hline 19 & $\begin{array}{l}\text { Menunjukkan kegemaran membaca dan menulis naskah } \\
\text { pendek sederhana; } \\
\text { memunjukkan keterampilan menyimak, berbicara, } \\
\text { bahasa Inggris sederhana; }\end{array}$ \\
\hline 20 & $\begin{array}{l}\text { Menguasai pengetahuan yang diperlukan untuk mengikuti } \\
\text { pendidikan menengah; }\end{array}$ \\
\hline 21 & Memiliki jiwa kewirausahaan. \\
\hline
\end{tabular}

\section{Metode Penelitian}

Penelitian ini menggunakan metode penelitian naturalistic dengan pendekatan kualitatif. Penelitian dilakukan pada bulan April-November 2015 di Mts Wahid Hasyim dan SMPN 2 Klaten. Subjek penelitian terdiri dari 2 orang kepala sekolah, 8 orang guru, 4 tenaga kependidikan, dan 8 orang siswa. Teknik pengumpulan data dilakukan melalui: wawancara, observasi, dan dokumentasi. Teknik analisis data menggunakan teknik analisis data interaktif model Miles \& Huberman meliputi empat kegiatan yaitu: pengumpulan data, display data, reduksi data, dan terakhir verifikasi atau pengambilan simpulan. Keabsahan data diperoleh melalui triangulasi dan perpanjangan pengamatan sehingga data yang diperoleh diharapkan sesuai dengan fenomena yang sebenarnya.

\section{Hasil Penelitian}

Guru MTs. Wahid Hasyim memiliki pemahaman yang memadai tentang pendidikan karakter berbasis pesantren. Pendidikan karakter berbasis pesantren di dianggap sebagai proses pendidikan dimana siswa dididik sesuai dengan nilai-nilai dan norma-norma yang terintegrasi dalam pendidikan pesantren. Pilar karakter yang dijadikan sebagai karakter inti dari santri Wahid Hadyim antara lain: pertama: akhlakul karimah, kedua: tahfidzul Qur'an, ketiga: bahasa, dan keempat: kitab kuning. PP 
Wahid Hasyim mempunyai harapan agar seluruh santri mempunyai akhlak yang baik (akhlaqul karimah) dengan meneladani sosok Rasulullah yaitu Nabi Muhammad, Saw., dan para sahabatnya yang telah teruji dalam sejarah sebagai gerakan revolusi moral yang telah membawa manusia kembali kepada jalan yang benar.

Implemantasi pendidikan karakter berbasis pesantren di MTs Wahid Hasyim dilaksanakan pada seluruh mata pelajaran termasuk IPS. Nilai-nilai karakter khas yang terdapat di pesantren diintegrasikan dalam materi-materi pembelajaran sehingga suasana pembelajaran menjadi lebih religious dan berkarakter. Nilai-nilai karakter yang digunakan dalam pendidikan karakter berbasis pesantren berasal dari ajaran-ajaran agama dan kegiatan keseharian yang ada di pesantren.

Secara umum kita mengacu pada nilai-nilai karakter yang dibakukan secara nasional yaitu 18 karakter sebagaimana panduan pendidikan karakter dari dinas pendidikan. Kelebihan kami nilai-nilai yang ada di situ kan nilai-nilai yang bisa dimasukkan di dalam mata pelajaran, kalau kita kan di mata pelajaran iya, di kehidupan sehari-hari di asrama juga iya. Sehingga manakala ada anak yang beda dari yang lainnya biasanya kelihatan (Wawancara dengan MLM, tanggal 18 Juni 2015)

Implementasi pendidikan karakter dalam kegiatan pembelajaran IPS di MTs Wahid Hasyim dilaksanakan mulai dari kegiatan perencanaan pembelajaran, pelaksanaan kegiatan pembelajaraan dan evaluasi setelah selesai pembelajaran. Dalam RPP guru telah merancang kegiatan pembelajaran yang mengintegrasikan nilai-nilai karakter sesuai dengan materi yang akan diajarkan. Kemudian dalam praktek pembelajaran guru selalu memulai kegiatan belajar dengan berdoa dan menghafalkan ayat-ayat dan surat-surat pendek di dalam Al Qur'an. 
Agus Sudarsono, Sudrajat, Satriyo Wibowo

Dari identifikasi peneliti ada beberapa karakter yang ditekankan selama proses pembelajaran yang dapat dilihat dalam table berikut:

Tabel. 2 Nilai-nilai Inti Pendidikan Karakter di MTs. Wahid Hasyim

\begin{tabular}{|c|c|c|}
\hline $\mathrm{NO}$ & $\begin{array}{c}\text { Nilai } \\
\text { karakter }\end{array}$ & Wujud implementasi \\
\hline 1. & Religius & $\begin{array}{l}\text { - Peserta didik berdoa sebelum pelajaran } \\
\text { - Guru mengajak peserta didik berdoa } \\
\text { setelah pelajaran } \\
\text { - Mengawali belajar dengan niat yang baik } \\
\text { dari peserta didik }\end{array}$ \\
\hline 2. & $\begin{array}{l}\text { Sopan } \\
\text { santun }\end{array}$ & $\begin{array}{l}\text { - Guru mengucapkan salam kepada peserta } \\
\text { didik } \\
\text { - Peserta didik berpamitan dan mencium } \\
\text { tangan guru setelah } \\
\text { pembelajaran selesai } \\
\text { - Peserta didik bersikap santun saat } \\
\text { menemui guru atau masuk ke ruang guru }\end{array}$ \\
\hline 3. & $\begin{array}{l}\text { Jujur dan } \\
\text { berani } \\
\text { berpendapat }\end{array}$ & $\begin{array}{l}\text { - Guru memberi kesempatan bagi peserta } \\
\text { didik mengemukakan pendapat sesuai } \\
\text { dengan apa yang diyakininya } \\
\text { - Peserta didik menanyakan materi yang } \\
\text { belum dipahami dan menyampaikan } \\
\text { sanggahannya kepada guru dengan sopan } \\
\text { santun } \\
\text { - Peserta didik mengerjakan sendiri tugas } \\
\text { individu dari guru }\end{array}$ \\
\hline 4. & $\begin{array}{l}\text { Rasa ingin } \\
\text { tahu }\end{array}$ & $\begin{array}{l}\text { - Melakukan apersepsi di awal pembelajaran } \\
\text { - Guru menggunakan berbagai media dan } \\
\text { pendekatan dalam pembelajaran } \\
\text { - Guru menggunakan metode pembelajaran } \\
\text { yang kreatif untuk menanamkan nilai-nilai } \\
\text { karakter pesantren pada peserta didik } \\
\text { - Guru mengkaitkan materi pelajaran yang } \\
\text { disampaikan dengan nilai-nilai karakter } \\
\text { pesantren yang ingin ditanamkan }\end{array}$ \\
\hline 5. & $\begin{array}{l}\text { Kedisiplinan } \\
\text { dan } \\
\text { kesungguhan }\end{array}$ & $\begin{array}{l}\text { - Guru mengecek kehadiran peserta didik } \\
\text { - Guru mengecek kerapian peserta didik } \\
\text { - Peserta didik mengerjakan tugas yang } \\
\text { diberikan oleh guru dengan sabar dan teliti } \\
\text { - Guru memberikan kesempatan peserta } \\
\text { didik untuk membaca materi dari buku/ } \\
\text { sumber lain }\end{array}$ \\
\hline
\end{tabular}




\begin{tabular}{|c|c|c|}
\hline & & $\begin{array}{l}\text { - Peserta didik memberikan catatan tentang } \\
\text { hal-hal yang penting yang disampaikan } \\
\text { oleh pendidik } \\
\text { - Guru melakukan evaluasi untuk } \\
\text { mengetahui sejauh mana kemampuan } \\
\text { peserta didik } \\
\text { - Peserta didik fokus pada materi pelajaran } \\
\text { yang sedang dipelajari di kelas } \\
\text { - Guru membiasakan hadir tepat waktu } \\
\text { untuk memberikan contoh yang baik bagi } \\
\text { peserta didik } \\
\text { - Guru berpakaian rapi untuk memberikan } \\
\text { contoh yang baik bagi peserta didik }\end{array}$ \\
\hline 6. & $\begin{array}{l}\text { Saling } \\
\text { menghargai }\end{array}$ & $\begin{array}{l}\text { - Guru melibatkan peserta didik /santri } \\
\text { mencari informasi yang luas tentang } \\
\text { materi pembelajaran } \\
\text { - Guru melakukan penilaian terhadap } \\
\text { pelaksanaan pendidikan karakter dalam } \\
\text { pembelajaran } \\
\text { - Peserta didik bertata krama yang baik } \\
\text { kepada guru sebagai bentuk sikap } \\
\text { menghargai }\end{array}$ \\
\hline 7. & $\begin{array}{l}\text { Hormat dan } \\
\text { Patuh } \\
\text { terhadap } \\
\text { perintah } \\
\text { guru }\end{array}$ & $\begin{array}{l}\text { - Peserta didik mengikuti kegiatan } \\
\text { pembelajaran dengan tetib dan lancar } \\
\text { - Peserta didik patuh dan taat terhadap } \\
\text { perintah guru } \\
\text { - Patuh ketika diminta membaca pelajaran } \\
\text { dan menjawab pertanyaan }\end{array}$ \\
\hline 8. & $\begin{array}{l}\text { Tanggung } \\
\text { jawabdan } \\
\text { mandiri }\end{array}$ & $\begin{array}{l}\text { - Guru memberikan tugas individu kepada } \\
\text { peserta didik } \\
\text { - Guru memfasilitasi peserta didik untuk } \\
\text { memecahkan masalah } \\
\text { pembelajaran dalam } \\
\text { - Peserta didik bertanggung jawab dengan } \\
\text { berpartisipasi aktif dalam kelompok } \\
\text { - Guru membimbing peserta didik } \\
\text { menyimpulkan materi }\end{array}$ \\
\hline 9. & $\begin{array}{l}\text { Musyawarah } \\
\text { dan } \\
\text { kerjasama }\end{array}$ & $\begin{array}{l}\text { - Peserta didik saling membantu satu sama } \\
\text { lain dalam mengerjakan tugas kelompok } \\
\text { - Guru memafasilitasi peserta didik untuk } \\
\text { bertukar pendapat dan bermusyawarah } \\
\text { - Guru memberikan kesempatan peserta } \\
\text { didik untuk berdiskusi (musyawarah) } \\
\text { dalam penyelesaian masalah }\end{array}$ \\
\hline 10. & Rendah hati & - Peserta didik berpenampilan sederhana \\
\hline
\end{tabular}


Agus Sudarsono, Sudrajat, Satriyo Wibowo|

\begin{tabular}{|c|l|l|}
\hline 11. & $\begin{array}{l}\text { hidup } \\
\text { sederhana } \\
\text { lingkungan }\end{array}$ & $\begin{array}{l}\text { dan tidak berlebih-lebihan } \\
\text { - Guru menyampaikan pesan moral kepada } \\
\text { peserta didik untuk menjaga kelesetarian } \\
\text { lingkungan dan memanfaatkan kekayaan } \\
\text { alam dengan sebaik-baiknya }\end{array}$ \\
\hline 12. & $\begin{array}{l}\text { Cinta tanah } \\
\text { air }\end{array}$ & $\begin{array}{l}\text { - Guru menyampaikan pesan moral kepada } \\
\text { peserta didik untuk melestarikan budaya } \\
\text { Indonesia dan menghargai jasa pahlawan }\end{array}$ \\
\hline 14. & $\begin{array}{l}\text { Toleransi } \\
\text { kesetaraan } \\
\text { kepada sayang } \\
\text { sesama dan } \\
\text { cinta damai }\end{array}$ & $\begin{array}{l}\text { Guru membentuk kelompok dengan latar } \\
\text { belakang yang berbeda } \\
\text { - Guru memberikan perlakuan yang sama } \\
\text { kepada seluruh peserta didik tanpa ada } \\
\text { diskriminasi }\end{array}$ \\
$\begin{array}{l}\text { Adanya interaksi dan komunikasi yang } \\
\text { paik antara guru dengan peserta didik dan } \\
\text { lain didik dengan peserta didik yang } \\
\text { Guru menegur peserta didik yang } \\
\text { melanggar peraturan } \\
\text { - Peserta didik bergaul dengan sesama } \\
\text { teman dengan akhlak terpuji dan berusaha } \\
\text { menjaga hubungan baik dengan teman }\end{array}$ \\
\hline
\end{tabular}

(Sumber: Data primer yang diolah peneliti)

Penilaian terhadap karakter siswa juga tidak hanya dilaksanakan dalam ranah kognitif tetapi juga dalam ranah afektif dan psikomotor. Guru mempunyai catatan-catatan kejadian yang merekam aktivitas dan kegiatan siswa selama di sekolah. Jadi setiap siswa mempunyai raport afektif yang dapat dijadikan sebagai bahan refleksi antara sekolah dan orang tua/wali untuk pengembangan karakter dan moralitas siswa yang bersangkutan. Raport afektif disusun dari jurnal-jurnal kejadian atau catatancatatan dari guru, ustadz, pengasuh, dan karyawan pondok pesantren.

SMP Negeri 2 Klaten merupakan sekolah yang sudah mengimplementasikan pendidikan karakter sejak beberapa tahun yang lalu. Hal tersebut merupakan respons dari menguatnya nilai- 
nilai, karakter dan etika sebagai keprihatinan terhadap perkembangan bangsa Indonesia yang mengalami keterpurukan dalam bidang moralitas dan kultural. Pendidikan Karakter di SMP Negeri 2 Klaten telah dilaksanakan sejak tahun 2010, namun semakin difokuskan semenjak tahun 2012 sesuai dengan Permen No. 21 mengenai pendidikan karakter yang mensyaratkan sekolah dan satuan pendidikan melaksanakan pendidikan karakter.

Nilai-nilai pendidikan karakter diintegrasikan kedalam berbagai kegiatan seperti Kegiatan Belajar Mengajar (KBM), kegiatan ekstrakurikuler, budaya sekolah, serta berbagai kegiatan di SMP Negeri 2 Klaten. Nilai-nilai karakter yang dikembangkan di SMP Negeri 2 Klaten berupa nilai religius, disiplin, jujur, jiwa kompetensi, cinta tanah air, kreatif dan peduli lingkungan, nilainilai ini di tanamkan kepada seluruh warga sekolah sehingga tujuan dalam pembentukan karakter siswa yang berakhlak dapat terwujud. Hal ini diungkapkan oleh kepala SMPN 2 Klaten sebagai berikut:

Program nilai-nilai karakter yang dikembangkan sudah dituangkan ke dalam visi dan misi sekolah. Nilai-nilai tersebut antara lain: nilai religius, disiplin, jujur, jiwa kompetensi, cinta tanah air, kreatif dan peduli lingkungan (wawancara dengan WS tanggal 30 September 2015).

Nilai-nilai yang dipilih untuk dikembangkan oleh SMPN 2 Klaten dapat dilihat dalam tabel 2 berikut ini:

Tabel 3. Nilai-nilai Inti dalam Pendidikan Karakter di SMPN 2 Klaten

\begin{tabular}{|l|c|c|}
\hline No. & Nilai & \multicolumn{1}{|c|}{ Bentuk Pelaksanaan kegiatan } \\
\hline 1. & Religius & $\begin{array}{l}\text { a. memulai dan mengakhiri pembelajaran } \\
\text { dengan doa } \\
\text { b. bagi siswa muslim jika waktu shalat tiba ada } \\
\text { kewajiban untuk melakukan shalat } \\
\text { c. sebelum pembelajaran di mulai ada kegiatan } \\
\text { keagamaan, bagi siswa muslim membaca } \\
\text { Al_Qur'an dan bagi siswa non muslim }\end{array}$ \\
\hline
\end{tabular}


Agus Sudarsono, Sudrajat, Satriyo Wibowo|

\begin{tabular}{|c|c|c|}
\hline & & $\begin{array}{l}\text { membaca sesuai agama dan kepercayaannya } \\
\text { d. selalu menjaga hubungan baik dengan } \\
\text { Tuhan dan sesama manusia menjaga sopan } \\
\text { santun } \\
\text { e. mampu memberikan dan menjadi contoh } \\
\text { yang baik dalam perbuatan }\end{array}$ \\
\hline 2. & Disiplin & $\begin{array}{l}\text { a. Masuk area sekolah apabila di antar harus } \\
\text { turun sesuai dengan batas pengantar } \\
\text { b. Memakai atribut sekolah elngkap } \\
\text { c. Mengikuti upacara bendera setiap hari Senin } \\
\text { d. Ada buku saku tata tertib siswa } \\
\text { e. Berpakaian seragam sopan, rapi dan sesuai } \\
\text { dengan jadwal } \\
\text { f. Kebiasaan } 3 S \text { dilakukan oleh seluruh warga } \\
\text { sekolah } \\
\text { g. Memberikan ssanksi yang adil bagi setiap } \\
\text { bentuk tindak pelanggaran } \\
\text { h. Pemasangan slogan-slogan dan tata tertib } \\
\text { sekolah, tentang kedisiplinan, cinta } \\
\text { lingkungan, cinta kebersihan } \\
\text { i. Mampu menyelesaikan tugas sekolah } \\
\text { dengan tepat waktu } \\
\text { j. Tidak malas, dan selalu giat dalam belajar } \\
\text { untuk meraih cita-cita } \\
\text { k. Tanggung jawab dalam segala kewajiban dan } \\
\text { perbuatan }\end{array}$ \\
\hline 3. & $\begin{array}{l}\text { Peduli } \\
\text { lingkung } \\
\text { an }\end{array}$ & $\begin{array}{l}\text { a. Menghargai segala macam bentuk budaya } \\
\text { lokal } \\
\text { b. Menjaga kebersihan lingkungan } \\
\text { c. Pembiasaan untuk mencintai lingkungan } \\
\text { dan tidak merusak lingkungan } \\
\text { d. Melakukan berbagai kegiatan lingkungan } \\
\text { dan kemanusiaan seperti bekerja bakti dan } \\
\text { bakti sosial } \\
\text { e. Suka menolong } \\
\text { f. Memiliki kepedulian terhadap lingkungan } \\
\text { fisik maupun lingkungan sosial } \\
\text { g. Lomba kebersihan } \\
\text { h. Pembuatan sistem draiasi }\end{array}$ \\
\hline 4. & Jujur & $\begin{array}{l}\text { a. Adanya kantin kejujuran } \\
\text { b. Larangan mencontek dan bekerjasama saat } \\
\text { ujian } \\
\text { c. Menyediakan fasilitas temuan barang yang } \\
\text { hilang di ruang piket } \\
\text { d. Jujur dalam setiap perilaku baik dalam }\end{array}$ \\
\hline
\end{tabular}




\begin{tabular}{|c|c|c|}
\hline & & dengan teman \\
\hline 5. & $\begin{array}{l}\text { Jiwa } \\
\text { Kompete } \\
\text { nsi }\end{array}$ & $\begin{array}{l}\text { a. Mampu mengerjakan tugas sekolah dengan } \\
\text { mandiri tanpa harus bergantung kepada } \\
\text { teman } \\
\text { b. Berpikir optimis dan positif menghadapi } \\
\text { masa depan } \\
\text { c. Pantang menyerah } \\
\text { d. Mampu berprestasi dan berkompetisi } \\
\text { dengan peserta didik yang lain } \\
\text { e. Terbuka terhadap kritik dan saran dari } \\
\text { orang lain } \\
\text { f. Mengasah bakat dan kemampuan yang } \\
\text { dimiliki dengan mengikuti berbagai } \\
\text { g. Pelaksanaan KIR } \\
\text { h. Macam kegiatan yang di adakan di sekolah } \\
\text { i. Pelatihan OSIS } \\
\text { j. Pelatihan Kepemimpinan }\end{array}$ \\
\hline 6. & Kre & $\begin{array}{l}\text { a. Mampu menyelesaikan masalah yang } \\
\text { dihadapi dengan bijak } \\
\text { b. Memanfaatkan barang-barang yang dapat di } \\
\text { daur ulang } \\
\text { c. Membuat kegiatan yang dapat menunjang } \\
\text { kreatifitas dan mengembangkan bakat serta } \\
\text { prestasi }\end{array}$ \\
\hline 7. & $\begin{array}{l}\text { Cinta } \\
\text { tanah } \\
\text { air }\end{array}$ & $\begin{array}{l}\text { a. Ikut upacara bendera } \\
\text { b. Menyanyikan lagu wajib } \\
\text { c. Mempertahankan kemerdekaan dengan giat } \\
\text { belajar dan berprestasi } \\
\text { d. Tidak melakukan tindakan terorisme yang } \\
\text { dapat mengganggu ketenangan dan } \\
\text { kenyamanan } \\
\text { e. Lomba 17-an }\end{array}$ \\
\hline
\end{tabular}

Langkah-langkah yang dilakukan dalam perencanaan pendidikan karakter di SMPN 2 Klaten sebagai berikut:

a. Sosialisasi, sosialisasi kepada kepal sekolah dan kurikulum melalui kegiatan workshop yang dilakukan Dinas Pendidikan Menengah dan Kejuruan oleh tim Pusat Kurikulum. Tujuannya adalah menyampaikan tentang konsep pendidikan karakter di sekolah. 
Agus Sudarsono, Sudrajat, Satriyo Wibowo

b. Pengembangan kurikulum, hal ini memuat nilai dilakukan oleh bagian kurikulum. Kegiatan workshop biasanya akan dilakukan semacam pelatihan kepada guru-guru tentang bagaimana cara mengembangkan silabus, RPP, dan perangkat pembelajaran yang memuat nilai-nilai karakter. Tujuannya adalah persamaan persepsi tentang proses implementasi nilai karakter dalam proses pembelajaran dan kegiatan di sekolah.

c. Membuat tujuan perencanaan dari latar belakang pendidikan karakter dituangkan kedalam visi misi dan tata tertib yang telah disepakati. Peraturan sekolah terutama buku saku siswa dibuat oleh kesiswaan yang kemudian diisi peeraturan tata tertib dan berbagai point pelanggaran yang disepakati oleh pihak komite sekolah, kepala sekolah, dan dewan kesiswaan.

Bagi setiap peserta didik yang baru masuk menjadi peserta didik di SMP Negeri 2 klaten diwajibkan membawa minimal 1 tanaman sebagai salah satu bentuk penghijauan dan upaya membebaskan lingkungan dari polusi. Menciptakan lingkungan bersih dilaksanakan dengan menjaga kebersihan fasilitas sekolah, larangan membawa kendaraan bermotor bagi siswa, larangan membuang sampah sembarangan, dan lain-lain. Penanaman nilainilai kecintaan pada lingkungan juga diimplementasikan dalam kegiatan pembelajaran dengan menyisipkan pesan-pesan lingkungan ke dalam berbagai mata pelajaran. Hal tersebut sejalan dengan upaya sekolah untuk menumbuhkan kultur (budaya) sekolah yang bersih, sehat, dan edukatif. Menciptakan kultur sekolah yang konstruktif sangat penting karena kultur yang sehat akan menggerakkan warga sekolah menjadi pribadi yang sehat dan berkarakter mulia. 


\section{Perbandingan Pendidikan Karakter di SMPN 2 Klaten dan Mts. Wahid Hasyim}

Wahid Hasyim mengembangkan model pendidikan yang menggunakan beberapa kurikulum antara lain: kurikulum pesantren, kurikulum departemen agama, dan kurikulum departemen pendidikan nasional. Secara umum mempunyai mata pelajaran inti yang sama dengan sekolah umum, namun dengan memberikan penambahan pada mata pelajaran agama karena menyesuaikan visi dan misi yayasan yang berafiliasi pada agama tertentu (Islam). Pelajaran bahasa Arab, pemahaman terhadap Al Qur'an dan Hadist menjadi prioritas dan dijadikan sebagai fondasi dalam mendidik santri atau siswanya untuk menjadi generasi Islam yang berakhlak mulia. Apa yang sudah ditanamkan, dipesankan, dan dipahamkan dalam kegiatan pembelajaran di kelas dapat ditindaklanjuti di asrama. Model demikian efektif dalam mengembangkan aspek-aspek sikap, emosi, dan perilaku karena memang lingkungan dan budaya yang mendukung bagi perkembangan sikap dan perilaku positif. Setiap kegiatan baik yang bersifat pribadi maupun kegiatan pendidikan dapat dipantau oleh ustadz, pengasuh pondok dengan baik mulai kegiatan di pagi hari yaitu persiapan ke madrasah sampai kegiatan menjelang tidur.

Sementara itu pendidikan karakter di sekolah umum (seperti di SMPN 2 Klaten) pada umumnya dilaksanakan pada jam efektif pembelajaran yaitu mulai jam 07.00-14.00 WIB. Implementasi pendidikan karakter pada SMPN 2 Klaten dilaksanakan terpadu di dalam seluruh kegiatan pendidikan baik kurikuler, maupun ekstrakurikuler. Dalam kegiatan kurikuler guru mengintegrasikan nilai-nilai karakter ke dalam pembelajaran. Kompetensi dasar yang diajarkan selalu dikaitkan dengan nilai- 
Agus Sudarsono, Sudrajat, Satriyo Wibowo

nilai tertentu baik dalam kegiatan pembelajaran maupun dalam evaluasi, sehingga berkembang semacam dialog moralitas dengan kasus tertentu. Guru berperan sebagai model dan teladan yang dituntut untuk memberikan contoh nyata bagaimana berbuat dan bertindak secara moralis. Dalam kegiatan ekstrakurikuler guru dan instruktur juga mencoba untuk menyisipkan pesan-pesan moralitas kepada siswa. Beberapa guru agama bahkan mensponsori sholat berjama'ah di masjid sekolah yang dilanjutkan dengan tausyiah yang mengingatkan kembali akan arti pentingnya pribadi yang mempunyai perilaku yang terpuji.

Hambatan yang dihadapi oleh MTs Wahid Hasyim maupun SMPN2 Klaten pada umumnya sama yaitu: belum kuatnya koordinasi dan komitmen diantara pemangku kepentingan yaitu masyarakat, keluarga (orang tua/wali), guru, dan karyawan. Pada umumnya masih ada beberapa guru yang berperilaku kontraproduktif dengan nilai-nilai tertentu, misalnya guru terlambat datang ke sekolah. Meskipun frekuensinya jarang, namun hal ini tetap memberikan dampak negative bagi implementasi pendidikan karakter, karena memberikan preseden yang buruk dimana guru yang seharusnya member contoh disiplin tidak dapat melaksanakan apa yang seharusnya.

\section{Simpulan}

Implementasi pendidikan karakter di sekolah berasrama (boarding school) lebih efektif dari-pada di sekolah umum. Monitoring dan pengawasan guru, pengasuh pondok, dan lingkungan yang konstruktif menjadikan inkulkasi nilai yang dilaksanakan selama kegiatan pembelajaran dan kegiatan pendidikan lainnya dapat berjalan dengan baik. Setiap kegiatan baik yang bersifat pribadi maupun kegiatan pendidikan dapat 
dipantau oleh ustadz, pengasuh pondok dengan baik mulai kegiatan di pagi hari yaitu persiapan ke madrasah sampai kegiatan menjelang tidur. Dengan demikian maka nilai-nilai khas pesantren disesuaikan dengan nilai-nilai yang berkembang di sekolah, tradisi dan budaya di sekeliling, keinginan warga sekolah, kehendak para pemegang kepentingan di sekolah, kondisi lingkungan dan sebagainya sehingga dapat diimplementasi-kan dalam kegiatan sekolah. Sementara itu pada sekolah umum, sekolah tidak dapat melakukan pengawasan dan monitoring selama siswa berada di luar sekolah, apalagi ketika berada di rumah.

\section{Daftar Pustaka}

Ali Muhtadi. (2006). Penanaman nilai-nilai agama Islam dalam pembentukan sikap dan perilaku siswa Sekolah Dasar Islam Terpadu Luqman Al-Hakim Yogyakarta. Jurnal Penelitian dan Evaluasi Pendidikan, 1, 50-61.

Anwar Sutoyo. (2009). Pemahaman individu: Observasi, checklist, kuesioner \& sosiometri. Semarang: CV Widya Karya.

Barry, V. (1985). Applying ethics: A text with readings. California: Wadworth Publishing Company.

Darmiyati Zuchdi. (2008). Humanisasi Pendidikan: Menemukan Kembali Pendidikan yang Manusiawi. Jakarta: Bumi Aksara.

Depdiknas. Undang-undang Nomor 20 Tahun 2003 tentang Sistem Pendidikan Nasional.

Doni Koesoema A. (2007). Pendidikan Karakter: Strategi Mendidik Anak di Zaman Global. Jakarta: PT Gramedia Widiasarana Indonesia.

E, Mulyasa. (2013). Manajemen Pendidikan Karakter. Jakarta: Bumi Aksara 
Agus Sudarsono, Sudrajat, Satriyo Wibowo

Fatchul Mu'in, (2011). Pendidikan Karakter Konstruksi Teoritik \& Praktik. Jogjakarta: Ar-Ruzz Media.

Kaswardi, EM. K., ed. (1993). Pendidikan Nilai Memasuki Tahun 2000. Jakarta: Grasindo.

Kirschenbaum, H. (1995). 100 Ways to Enhance Values and Morality in Schools and Youth Settings. Boston: Allyn and Bacon.

Krathwohl, David R., Bloom, Benjamin S., \& Masia Bertram B. (1964). Taxonomy of Educational Objectives: The Classification of Educational Goals Handbook II: Affective Domain. London: Longman Group Ltd.

Kurotul Aeni \& Sudaryanto. (2005). Proses Pendidikan Budi Pekerti di Taman Muda Majelis Ibu Pawiyatan Tamansiswa Yogyakarta, Jurnal Penelitian dan Evaluasi, 7, 23-39.

Kusnaedi. (2013). Strategi dan Implementasi Pendidikan Karakter. Bekasi: Duta Media Tama.

Lickona, T. (1991). Education for Character: How Our School Can Teach Respect and Responsibility. New York: Bantam Books.

Margono. (2010). Metodologi Penelitian Pendidikan. Jakarta: Rineka Cipta.

Miles, Matthew B., \& Huberman, A. Michael. (1984). Qualitative Data Analysis: A Sourcebook of New Methods. London: Sage Publication.

Moleong J. Lexy. (2000). Metodologi Penelitian Kualitatif. Bandung: PT Remaja Rosdakarya.

Santo J.D. \& Cremers, A. (eds). (1995). Tahap Perkembangan Moral Lawrence Kohlberg. Yogyakarta: Kanisius.

Sembiring, S.S. (2010). Urgensi Pendidikan dengan Keteladanan. Tersedia dalam http://www.harianglobal.com/index.php?option $=$ com_content\&view $=$ article \&id=1523\%3Aguru-menulis-urgensi-pendidikan-denganketeladanan\&Itemid=53. Diunduh pada tanggal 5 April 2010 
JIPSINDO No. 1, Volume 3, Maret 2016

Sofan Amri, dkk. (2011). Implementasi Pendidikan Karakter dalam Pembelajaran. Jakarta: Prestasi Pustaka Publisher.

Sugiyono. (2008). Metode Penelitian Pendidikan: Kuantitatif, Kualitatif, $R \& D$. Bandung: Alfabeta.

Taylor, Paul W. (ed.). (1969). Problem of Moral Philosophy: An Introduction to Ethic. New York: Bantam Books.

Thornberg, R. (2010). Values Education as the Daily Fostering of School Rules. Research in Education, 80, 52-62.

Winch, Christopher. (2006). Education, Autonomy, and Critical Thinking. London: Routledge Taylor \& Francis Group.

Yani Maryani. (2010). Menelaah Pendidikan Nilai di Sekolah. Tersedia dalam http://pendis.depag.go.id/lama/cfm/index.cfm?fuseaction=Kaj ianBerita\&Berita $I d=8991 \& S u b=7$. Diunduh pada tanggal 18 Juni 2010.

Yildirim, K. (2009). Values Education Experiences of Turkish Class Teachers: A Phenomenological Approach. Egitim ArastirmalariEurasian Journal of Educational Research, 35, 165-184.

Zaim Elmubarok. (2008). Membumikan Pendidikan Nilai. Bandung: Alfabeta

Zamroni. (2000). Paradigma Pendidikan Masa Depan. Yogyakarta: Bigraf Publishing. 